Goldschmidt 2021 Abstract

https://doi.org/10.7185/gold2021.7627

\section{Geochemistry of low-Ti Siberian Traps sills from the Tunguska Basin bears evidence of magma-crust interaction}

\author{
SARA CALLEGARO ${ }^{1}$, HENRIK SVENSEN ${ }^{2}$, ELSE- \\ RAGNHILD NEUMANN ${ }^{3}$, ALEXANDER POLOZOV ${ }^{4}$, \\ DOUGAL A JERRAM ${ }^{5}$, FRANCES DEEGAN ${ }^{6}$ AND SVERRE \\ PLANKE $^{7}$ \\ ${ }^{1}$ Centre for Earth Evolution and Dynamics (CEED), University \\ of Oslo \\ ${ }^{2}$ University of Oslo \\ ${ }^{3}$ Centre for Earth Evolution and dynamics, University of Oslo \\ ${ }^{4}$ IGEM RAS \\ ${ }^{5}$ DougalEARTH Ltd. \\ ${ }^{6}$ Uppsala University \\ ${ }^{7}$ Volcanic Basin Petroleum Research (VBPR), Oslo Innovation \\ Center \\ Presenting Author: sara.callegaro@geo.uio.no
}

A vast portion of the plumbing system of the Siberian Traps Large Igneous Province (STLIP) is emplaced in the Tunguska Basin (TB), where borehole data reveal ubiquitous and abundant sills and dykes. These intrusions intersect Cambrian-Ordovician evaporite, carbonate and siliciclastic series, and locally coalbearing Permian host-rocks, with a high potential for thermogenic gas generation (Svensen et al., 2018). We had access to core and granulate samples from 5 boreholes intercepting sills down to ca. $4000 \mathrm{~m}$ below the surface, from the Tunguska Basin centre and periphery. New geochemical data from 71 magmatic and 4 sedimentary rock samples, recovered from 15 deep sills revealed the presence of low-Ti basalt and basaltic andesites, confirming absence of high-Ti and alkaline STLIP magmatism in the Tunguska Basin. This is also supported by low LREE/HREE and MREE/HREE ratios, confirming melting of a dominantly peridotitic source within the spinel stability field, typical of the main tholeiitic phase of the STLIP as opposed to deep, low-percentage melting of almost pure pyroxenite that produced the high-Ti earlier occurrences (Sobolev et al., 2011). Isotopes of $\mathrm{Sr}$ and $\mathrm{Nd}$ reveal two opensystem evolution pathways, one trending towards silicic crustal rocks and one towards Cambrian evaporites (fluid-mediated interaction). Geochemical correlations with the established oncraton STLIP lava piles and intrusions (Norilsk region; Fedorenko et al., 1996) allowed to correlate one sill with the strongly contaminated Nadezhdinsky lava Formation. All the remaining dolerites are geochemically similar to the Upper Series lava formations, from Morongovsky to Samoedsky and to the Norilsk type intrusions. These dolerites, present all across the central Tunguska Basin, bear strong evidence of interaction with evaporites and can represent the voluminous pulse of intrusive magmatism (Burgess et al., 2017) responsible for massive generation of thermogenic volatiles coincident with the endPermian environmental crisis.

Svensen HH, et al. (2018) Philos Trans R Soc A Math Phys
Eng Sci 376. doi.org/10.1098/rsta.2017.0080

Fedorenko VA, et al. (1996) Int Geol Rev 38:99-135. doi.org/10.1080/00206819709465327

Sobolev SV., et al. (2011) Nature 477:312-316. doi.org/10.1038/nature10385

Burgess SD, et al. (2017) Nat Comm 8:1-4. doi.org/10.1038/s41467-017-00083-9 